\title{
THE MEDIEVAL POPULATION OF POLOTSK ACCORDING TO THE ANTHROPOLOGICAL DATA
}

The aim of this study was to analyze human skeletal remains from $13^{\text {th }}-14^{\text {th }}$ centuries burials discovered in the territory of the Lower Castle in Polotsk, Belarus. The article deals with morphological characteristics of medieval urban population, mortality levels and skeletal stress indicators such as cribra orbitalia.

Keywords: Polotsk, $13^{\text {th }}-14^{\text {th }}$ centuries, craniology, paleodemography, cribra orbitalia.

Introduction. Polotsk (Polack) is one of the oldest city of Belarus and eastern Slavs. The first annalistic mention of Polotsk dates back to 862. In the $9^{\text {th }}$ century Polotsk was a tribal center of the Polotsk Krivichi. During this period, Polotsk was well known to the Scandinavians under the name Pal(l)teskia, Pallteskioborg. In the $10^{\text {th }}-11^{\text {th }}$ centuries, Polotsk became the center of the Principality of Polotsk, in which its independent princely dynasty rules. Unlike other Kievan Rus cities, in the $13^{\text {th }}$ century Polotsk did not experience the invasion of the Mongol-Tatars and Crusaders. At the beginning of the $14^{\text {th }}$ century Polotsk became part of the Grand Duchy of Lithuania. For a long time Polotsk became an important outpost in the north of the state, with the help of which the great princes of Lithuania spread their influence to neighboring Russian lands, and also fought against the Livonian Order.

Systematic anthropological studies of the ancient population of Polotsk have been carried out since 2005. In the course of many years of archaeological research which are carried out on the basis of Polotsk State University, a representative osteological collection was obtained, including materials from urban burials, dated mainly from the $17^{\text {th }}-18^{\text {th }}$ centuries. The results of a comprehensive anthropological study of these materials are reflected in a number of publications (Емельянчик 2012; Borutskaya, Vasilyev, Yemialyanchyk 2015).

In 2014, as a result of archaeological excavations at the foreland of the Lower Castle in Polotsk, which were conducted under the guidance of D. V. Duk and A. L. Kots, for the first time materials on the medieval population of Polotsk dated to the $13^{\text {th }}-14^{\text {th }}$ centuries were obtained. An anthropological study of these materials allows us to trace the characteristics of the formation of Polotsk population in the Middle Ages, to determine the nature of the relationship between urban and rural populations, to characterize the living conditions and general health status of Polotsk population in the Middle Ages.

Material and methods. Osteological series of the $13^{\text {th }}-14^{\text {th }}$ centuries from the territory of the Lower Castle in Polotsk is characterized by a mixed sex and age composition and is represented by skeletons of various degrees of conservation, which belonged to at least 61 individuals, including 12 subadults and 49 adults (24 males, 12 females, the gender of 13 individuals was not determined due to the fragmentary preservation of the skeletons). Subadults' remains make up about $19.7 \%$ of the total number of those buried, which most likely indicates an underestimation of children's burials, due to the worse preservation of poorly mineralized children's bones.

Sex and age were determined using standard methods. Sex was determined based on an assessment of the structural features of the skull and pelvic bones characteristic of men and women. When determining the adult age estimation, the extent of cranial suture closure combined with the degree of tooth wear was taken into account. The age of subadults skeletons was determined 
based on the degree of dental formation according to the Ubelaker's scheme (Ubelaker 1989, p. 64), the degree of ossification of different parts of the skeleton, as well as on the basis of a morphological criterion that takes into account bone size and maturation (Piontek 1996, p. 143). The sex and age determination results were used for paleodemographic analysis. When constructing life tables, the concept of a conditionally stationary population was used. The average age of death was calculated by multiplying the average of each age class by a fraction of this class. The average of the first age category (15-20 years) was taken equal to 17.5 years; the average of senile age was taken equal to 52.5 years respectively.

Measurement of craniological material with subsequent calculation of angles and indices was carried out using a standard technique (Алексеев, Дебец 1964). To evaluate the obtained indicators, tables of craniometric constants were used (Алексеев, Дебец 1964, p. 112-127). The reconstruction of the intravital body length was carried out on the basis of the measurement data of long bones according to the Trotter and Gleser method (Piontek 1996, p. 180-182).

The severity of cribra orbitalia (porosity and hyperostosis of the superior wall of the orbit) was estimated according to the Nathan and Haas scale: 1) porotic type consisting of isolated small pores on the bone surface; 2) cribrotic type, in which the pores are large and conglomerate, but still preserve their individuality; 3) trabecular type where the apertures have become confluent, and the bone remaining between them has been converted into a network of trabeculae (Nathan, Haas 1966, p. 351). The statistical significance of the intergroup differences in the occurrence of the trait was checked using the $\mathrm{X}^{2}$ test.

Research. Craniological study. Males. The state of skeletal material preservation allowed the measurement of 18 male skulls (table 1). The total series of male skulls is characterized by mesocrany, large longitudinal and average transverse diameter of skull in combination with high brain case. The face is average - in terms of absolute dimensions and upper facial index, orthognathic, well-profiled in horizontal plane with insignificant flattening at the level of orbits. The orbits are of average breadth and low — in terms of absolute dimensions and orbit index. The nose is characterized by average size of piriform aperture and high nose bridge.

As for the individual variations in the brain shape, eight out of 17 male skulls are characterized by dolichocrania, eight have a mesocranic form, and one is brachycranic. Inside the male sample, there are skulls with both a narrow and a wide (in by-zygomatic diameter) face. A variation in the height of the face is also observed: 4 skulls have a high and very high face, 5 skulls have a low face, and the rest are medium in height. According to the upper facial index, 5 skulls belong to the category of narrow-faced, 2 skulls - to the category of broad-faced; the remaining 7 have a face of medium width. According to the face profile index, most skulls are orthognathic, one is mesognathic, and one of the skulls is characterized by prognathism.

Despite the revealed variability of craniological signs, most of the standard deviations of the sample of male skulls are within the standard values (Алексеев, Дебец 1964, р. 123, 124), except for the face base length, the upper facial height and orbit height, the nose breadth and height.

Females. The state of skeletal material preservation allowed the measurements of only $7 \mathrm{fe}$ male skulls (table 1). In almost all indicators of the cerebral and facial parts of the skull, as well as in the angles of horizontal profiling, the female sample is similar to the male one. Like the men's, the women's series is characterized by mesocrania with large sizes of the longitudinal and altitudinal diameters of the skull, and medium - transverse, orthognathic, face average on the upper facial index. As in men, the face is slightly flattened at the level of the orbits, and is strongly profiled at the level of the cheekbones; the nose protrudes well, as evidenced by the high values of the dacrial and symotic indices.

Some differences between the female and male samples relate only to certain size categories. If in the male sample all sizes of the facial skeleton are classified as medium, then in the female sample, most of the absolute sizes (malar diameter, upper facial breadth, and upper facial height) belong to the category of large values.

Individual variations of the female sample are presented as follows: of 7 skulls, two are characterized by dolichocrania, three skulls have a mesocrane shape, and two have a brachicrania shape. According to the upper facial index, one skull belongs to the category of narrow-faced, the remaining three to the category of medium-faced. According to the index of the face protrusion, most skulls are orthognathic, mesognathism is marked on one skull.

The similarity of the signs of the neurocranium and viscerocranium of the skull, as well as signs characterizing the profile of the face and the degree of protrusion of the nasal bones, allows us to state the anthropological proximity between the female and male samples.

Comparison of a series of male skulls of the $13^{\text {th }}-14^{\text {th }}$ centuries from Polotsk with a chronologically close series of rural burial mounds of the $11^{\text {th }}-13^{\text {th }}$ centuries from the territory of Polotsk Land showed significant similarities in most absolute sizes (Емельянчик, Шипилло 2018, р. 20$22)$. The Polotsk series of the $13^{\text {th }}-14^{\text {th }}$ centuries naturally differs from the rural series of the $11^{\text {th }}-13^{\text {th }}$ centuries in higher skull index, which reflects the beginning of the epochal process of brachycephalization in the later Polotsk populations. In addition, Polotsk series of male skulls is 
Yemialyanchyk, V. A. The Medieval Population of Polotsk According to the Anthropological Data

Table 1. Average sizes and indices of male and female skulls from the $13-14^{\text {th }}$ centuries burial in Polotsk

\begin{tabular}{|c|c|c|c|c|c|c|c|}
\hline \multirow{2}{*}{$\begin{array}{l}\text { No, accord- } \\
\text { ing to Martin }\end{array}$} & \multirow{2}{*}{ Trait } & \multicolumn{3}{|c|}{ Males, 18} & \multicolumn{3}{|c|}{ Females, 7} \\
\hline & & $N$ & $M$ & $\mathrm{~S}$ & $\mathrm{~N}$ & M & $\mathrm{S}$ \\
\hline \multicolumn{8}{|c|}{ Neurocranium } \\
\hline 1 & Longitudinal diameter & 18 & 186.4 & 6.3 & 7 & 179.1 & 3.7 \\
\hline 8 & Transverse diameter & 17 & 140 & 4.6 & 7 & 138.6 & 6.4 \\
\hline 5 & Skull base length & 17 & 104 & 4.8 & 5 & 102.0 & 3.7 \\
\hline 9 & Breadth frontal minimum & 18 & 98.3 & 4.4 & 7 & 97.4 & 2.2 \\
\hline 10 & Breadth frontal maximum & 18 & 119.3 & 3.9 & 7 & 120.6 & 5.4 \\
\hline 12 & Occipital breadth & 17 & 109.2 & 4.6 & 7 & 106.3 & 3.0 \\
\hline 17 & Height diameter & 17 & 137.8 & 4.3 & 6 & 138.2 & 4.4 \\
\hline \multicolumn{8}{|c|}{ Viscerocranium } \\
\hline 45 & By-zygomatic diameter & 14 & 132.6 & 4.5 & 6 & 127.5 & 4.1 \\
\hline 43 & Upper facial breadth & 18 & 105.7 & 4.2 & 7 & 104.0 & 3.1 \\
\hline 46 & Medium facial breadth & 17 & 95.5 & 4.5 & 4 & 90.8 & 4.2 \\
\hline 40 & Face base length & 16 & 100.1 & 6.7 & 5 & 96.4 & 4.9 \\
\hline 48 & Upper facial height & 17 & 71.7 & 4.7 & 5 & 68.8 & 4.3 \\
\hline 51 & Orbit breadth & 17 & 42.5 & 1.4 & 5 & 41.2 & 2.1 \\
\hline 52 & Orbit height & 17 & 31.7 & 2.4 & 5 & 33.6 & 2.9 \\
\hline 54 & Nose breadth & 16 & 25.7 & 2.1 & 5 & 24.0 & 1.6 \\
\hline 55 & Nose height & 17 & 51.4 & 3.6 & 5 & 50.2 & 3.3 \\
\hline $\mathrm{DC}$ & Dacrial breadth & 15 & 22.0 & 2.2 & 5 & 21.4 & 0.6 \\
\hline $\mathrm{DS}$ & Dacrial height & 15 & 12.1 & 1.5 & 5 & 11.3 & 1.2 \\
\hline $\mathrm{SC}$ & Symotic breadth & 16 & 9.5 & 1.9 & 5 & 9.7 & 0.8 \\
\hline SS & Symotic height & 16 & 4.6 & 1.1 & 5 & 4.7 & 1.4 \\
\hline \multicolumn{8}{|c|}{ Indices } \\
\hline $8: 1$ & Skull index & 17 & 75.3 & 3.5 & 7 & 77.4 & 4.5 \\
\hline $40: 5$ & Face profile index & 16 & 96.0 & 3.0 & 5 & 94.6 & 4.7 \\
\hline $48: 45$ & Upper facial index & 14 & 54.0 & 3.7 & 4 & 53.6 & 3.2 \\
\hline $52: 51$ & Orbit index from mf. & 17 & 74.6 & 5.3 & 5 & 81.6 & 6.9 \\
\hline $54: 55$ & Nose index & 16 & 50.4 & 4.5 & 5 & 47.9 & 3.4 \\
\hline DS : DC & Dacrial index & 15 & 55.5 & 7.5 & 5 & 52.9 & 6.4 \\
\hline $\mathrm{SS}: \mathrm{SC}$ & Symotic index & 16 & 48.2 & 9.5 & 5 & 48.1 & 12.8 \\
\hline \multicolumn{8}{|c|}{ Horizontal profiling angles } \\
\hline 77 & Nasomalar angle & 17 & 140.0 & 3.4 & 5 & 140.6 & 4.2 \\
\hline $\mathrm{zm}$ & Zygomaxillar angle & 15 & 122.8 & 3.9 & 4 & 122.9 & 2.1 \\
\hline
\end{tabular}

statistically significantly different from the rural series in a higher face, a larger face profile index, as well as a lower nose bridge.

The female series of skulls from Polotsk differs from the mound female series in larger absolute sizes of the brain and facial sections. The comparison of Polotsk female series and the mound series with the use of the Student's t-criterion revealed nonrandom intergroup differences in longitudinal diameter and height diameter of the skull, skull base length and face base length, as well as upper facial breadth. Like the men's, Polotsk women's series is characterized by a larger skull index compared to the earlier rural series.

The fact that the urban series of male skulls of the $13^{\text {th }}-14^{\text {th }}$ centuries from Polotsk differs from the mound rural series of the $11^{\text {th }}-13^{\text {th }}$ centuries from the territory of Polotsk land in a complex of features that are not associated with secular trend and characterizing the structural features of the facial skeleton (a higher face with a smaller protrusion of the nose, a larger face profile index) may indicate genetic differences and participation in the formation of alien component in the anthropological composition of the later medieval Polotsk population.

The body length of adult men from Polotsk, reconstructed on the basis of measuring the long tubular bones of the limbs, varies within 162$175 \mathrm{~cm}$ and averages $169.5 \mathrm{~cm}$. The body length of adult women varies within $147-159 \mathrm{~cm}$ and averages $156 \mathrm{~cm}$. Compared with the later population of Polotsk $17^{\text {th }}-18^{\text {th }}$ centuries the medieval urban population was taller. So, the height of medieval men was $2.5 \mathrm{~cm}$ more than the height of the townspeople of the $17^{\text {th }}-18^{\text {th }}$ centuries, the 
medieval Polotsk women were on average $2 \mathrm{~cm}$ higher than the women of the $17^{\text {th }}-18^{\text {th }}$ centuries.

Paleodemographic analysis. For the studied osteological series, a life table was calculated (table 2). Due to the fact that the average life expectancy at birth is significantly distorted depending on the representativeness of the child part of the sample, the mortality rate of adults was analyzed. The average life expectancy without taking into account child mortality $\left(E_{20}\right)$ in the group of the Polotsk medieval population was 16.2 years. This means that individuals who have reached the age of 20 , on average, could expect to live another 16.2 years. The average age of adult death in the studied group was 35.1 years. The life expectancy of Polotsk women of the $13^{\text {th }}-14^{\text {th }}$ centuries was 3 years less than that of men.

The average life expectancy and the average age of death of Polotsk $13^{\text {th }}-14^{\text {th }}$ centuries urban population were 6 years lower than that of the medieval rural population represented by the materials of burial mounds of the $11^{\text {th }}-13^{\text {th }}$ centuries (Емельянчик 2015a, p. 322).

Cribra orbitalia (porosity and hyperostosis of the superior wall of the orbits) is currently considered to be an indicator of stress due to malnutrition and increased pathogenic load. Like demographic indicators, cribra orbitalia is a kind of generalizing criterion of the ancient population health status. Analysis of the incidence of cribra orbitalia in different populations allows a comparative assessment of the population general health status without taking into account the specific paleoepidemiological situation.

The group of Polotsk medieval population is characterized by increased frequencies of cribra orbitalia. Among adults, the indicator is present in $32.2 \%$ of cases, among children - in $55.5 \%$ of cases. These indicators are higher than those of the medieval rural population (14.7\% among adults and $50 \%$ among children). The differences in the frequencies of cribra orbitalia between medieval groups of rural and urban populations achieve statistical significance $\left(x^{2}=4.6, p<0.05\right)$.

Discussion. In general, higher incidence of cribra orbitalia were characteristic for the popu- lation of Polotsk $13^{\text {th }}-14^{\text {th }}$ centuries, as well as increased mortality compared to the medieval rural population. This indicates the deterioration in living conditions and the general state of health of the studied group of urban population in comparison with the earlier rural population.

As a hypothesis explaining the deterioration of the general health status of Polotsk residents compared with the rural population, we can consider the factor of urbanization. The negative impact of the urban environment was noted by A.P. Buzhilova in her study of a number of ancient Rus' cities. In particular, in urban groups there is an increase in the incidence of cribra orbitalia and tooth enamel hypoplasia, as well as a wider spread of bacterial infections, such as tuberculosis and syphilis (Бужилова 2005, p. 241, 242). These facts A.P. Buzhilova explains as the result in the increase of urban population density, in some cases - insufficient or poor-quality nutrition (Бужилова 2005, p. 241).

In addition to the noted factor of urbanization, one of the possible reasons for the deterioration of the general health of the Polotsk population in the $13^{\text {th }}-14^{\text {th }}$ centuries there could be climate changes that began in Europe in the fourteenth century. On the eve, in the $10^{\text {th }}-13^{\text {th }}$ centuries, the so-called "medieval climatic optimum» was observed, the era of a relatively warm climate. However, from the beginning of the $14^{\text {th }}$ century the period of relative cooling began, which lasted until the $19^{\text {th }}$ century (Борисенков 1988, p. 175). The direct consequence of the first phase of this so-called "small ice age» was the mass famine of the first half of the $14^{\text {th }}$ century in Europe. Only in the $14^{\text {th }}$ century in the annals there are more than 100 extreme natural phenomena, which resulted in 30 hungry years (Борисенков 1988, p. 179). A confirmation of the hypothesis of the influence of the climatic factor is the recorded earlier fact of an increase in the frequency of cribra orbitalia among Polotsk rural population land in the $13^{\text {th }}-16^{\text {th }}$ centuries in comparison with the "mound population" of the $11^{\text {th }}$ - beginning of the $13^{\text {th }}$ centuries (Емельянчик 2015b, с. 304).

Conclusions. As a result of the study, the following conclusions can be drawn.

Table 2. Life table

\begin{tabular}{|c|c|c|c|c|c|c|cc|}
\hline Age category & $D_{x}$ & $d_{x}$ & $l_{x}$ & $q_{x}$ & $L_{x}$ & $T_{x}$ & $E_{x}$ \\
\hline $0-7$ & 5 & 8.2 & 100.0 & 0.082 & 575.4 & 2903.3 & 29.0 \\
$7-15$ & 7 & 11.5 & 91.8 & 0.125 & 688.5 & 2327.9 & 25.4 \\
$15-20$ & 2 & 3.3 & 80.3 & 0.041 & 393.4 & 1639.3 & 20.4 \\
$20-30$ & 18.5 & 30.3 & 77.0 & 0.394 & 618.9 & 1245.9 & 16.2 \\
$30-40$ & 11.5 & 18.9 & 46.7 & 0.404 & 373.0 & 627.0 & 13.4 \\
$40-50$ & 10 & 16.4 & 27.9 & 0.588 & 196.7 & 254.1 & 9.1 \\
$50+$ & 7 & 11.5 & 11.5 & 1.000 & 57.4 & 57.4 & 5.0 \\
& 61 & 100 & - & - & - & - & - \\
\hline
\end{tabular}


The total male sample of skulls from medieval Polotsk is characterized by meso-dolichocrania, large sizes of the brain. The face is of medium size, orthognathic, well profiled at the level of the cheekbones and slightly flattened at the level of the orbits, with a strongly protruding nose. The female sample of skulls is similar to the male in most indicators, as well as in terms of characterizing the profile of the face and the degree of protrusion of the nasal bones. According to most craniological characteristics, a series of male skulls from Polotsk of the $13^{\text {th }}-14^{\text {th }}$ centuries is similar to a sample of the medieval rural population of Polotsk land from burial mounds of the $11^{\text {th }}-13^{\text {th }}$ centuries. The differences relate to an increase in the cranial index in the later Polotsk series, which reflects the onset of the epochal process of brachycephalization. In addition, Polotsk urban population differs from the rural population in a number of features of the facial skeleton (a higher face, a larger index of facial protrusion, a smaller protrusion of the nose). These differences can be genetically determined and indicate the participation of the alien component in the formation of Polotsk medieval population.

The body length of adult men from Polotsk varies within $162-175 \mathrm{~cm}$ and averages $169.5 \mathrm{~cm}$. The body length of adult women varies within $147-159 \mathrm{~cm}$ and averages $156 \mathrm{~cm}$. Compared to the later Polotsk population of the $17^{\text {th }}-18^{\text {th }}$ centuries, the medieval urban population was taller (2.5 $\mathrm{cm}$ in men and $2 \mathrm{~cm}$ in women).

The average age of adult death in the studied group was 35.1 years. The average age of death for Polotsk women was 3 years less than for men. The group of Polotsk medieval population is characterized by relatively high frequencies of cribra orbitalia. Among adults, the indicator is present in $32.2 \%$ of cases, among children - in $55.5 \%$ of cases.

Compared with the rural population of the $11^{\text {th }}-13^{\text {th }}$ centuries urban population of Polotsk of the $13^{\text {th }}-14^{\text {th }}$ centuries had higher mortality rates and increased incidence of cribra orbitalia, which indicates deterioration in general health in Polotsk urban population. The most probable causes of this phenomenon were, on the one hand, negative factors of urbanization, and on the other hand, the cooling of the climate, which began in Europe in the $14^{\text {th }}$ century and led to deterioration in the living conditions of a significant part of the region's population.

\section{ЛITEРАТУРА}

Алексеев, В. П., Дебец, Г. Ф. 1964. Краниолетрия. Методика антропологических исследований. Москва: Наука.

Борисенков, Е. П. 1988. Тьсячелетняя летопись необычайных явлений природы. Москва: Мысль.

Бужилова, А. П. 2005. Ното sapiens: История болезни. Москва: Языки славянской культуры.
Емельянчик, О.А. 2012. Антропологический анализ погребений XVII-XVIII вв. с территории Полоцка. В: Коваленя, А. А., Левко, О. Н. (ред.). Полоик: Полоик и Полоикое княжество (земля) в IXХIII вв., летопись древних слоев, Полоик и его округа в XIV-XVIII вв., релесло, денежное обрашение и торговые связи Полоцка в средневековье. Минск: Беларуская навука, с. 165-176.

Емельянчик, О.А. 2015а. Палеодемография городского и сельского населения Беларуси. В: Саливон, И. И., Васильев, С. В. (ред.). ПалеоантропологияБеларуси.Минск:Беларускаянавука,с. 309338.

Емельянчик, О.А. 2015b. Формирование научных представлений об этиологии и патогенезе cribra orbitalia и встречаемость этого индикатора анемического стресса среди населения Беларуси на протяжении II тысячелетия н. э. В: Саливон, И. И., Васильев, С. В. (ред.). Палеоантропология Беларуси. Минск: Беларуская навука, с. 283-305.

Емельянчик, О. А., Шипилло, В. А., 2018. Краниологическая характеристика материалов погребений с территории Нижнего Замка в Полоцке. Вестник Полоцкого государственного университета. Серия A, гуманитарные науки, 1, с. 18-23.

Borutskaya, S. B., Vasilyev, S. V., Yemialyanchyk, V.A. 2015. The Population of Polotsk in the 17$18^{\text {th }}$ Centuries According to Anthropological Data. International Journal of Anthropology, V, 30, 1, p. 27-42.

Nathan, H., Haas, N. 1966. On the presence of cribra orbitalia in apes and monkeys. American Journal of Physical Anthropology, V, 24, p. 351-360.

Piontek, J. 1996. Biologia populacji pradziejowych. Zarys metodyczny. Poznań: UAM.

Ubelaker, D.H. 1989. Human skeletal remains. Excavation, analysis, interpretation. Washington: Taraxacum.

\section{REFERENCES}

Alekseev, V. P., Debets, G. F. 1964. Kraniometriya. Metodika antropologicheskih issledovanij. Moskva: Nauka.

Borisenkov, E. P. 1988. Tysyacheletnyaya letopis' neobychajnyh yaulenij prirody. Moskva: Mysl'.

Buzhilova, A. P. 2005. Homo sapiens: Istoriya bolezni. Moskva: Yazyki slavyanskoj kul'tury.

Emelyanchik, O. A. 2012. Antropologicheskij analiz pogrebenij XVII-XVIII vv. s territorii Poloczka. In: Kovalyenya, A. A., Levko, O. N. (eds.). Poloczk: Poloczk i Poloczkoe knyazhestvo (zemlya) v IX-XIII vv., letopis' drevnih sloev, Poloczk $i$ ego okruga v XIV-XVIII vv., remeslo, denezhnoe obrashhenie i torgovye suyazi Poloczka v srednevekovje. Minsk: Biełaruskaja navuka, s. 165-176.

Emelyanchik, O. A. 2015a. Paleodemografiya gorodskogo i sel'skogo naseleniya Belarusi. In: Salivon, I. I., Vasilev, S. V. (eds.). Paleoantropologiya Belarusi. Minsk: Biełaruskaja navuka, s. 309-338.

Emelyanchik, O. A. 2015b. Formirovanie nauchnyh predstavlenij ob etiologii i patogeneze cribra orbitalia i vstrechaemost' etogo indikatora anemicheskogo stressa sredi naseleniya Belarusi na protyazhenii II tysyacheletiya n. e. In: Salivon, I. I., Vasilev, S. V. (eds.). Paleoantropologiya Belarusi. Minsk: Biełaruskaja navuka, s. 283-305.

Emelyanchik, O.A., Shipillo, V.A., 2018. Kraniologicheskaya harakteristika materialov pogrebenij s territorii Nizhnego Zamka v Poloczke. Vestnik Poloczkogo gosudarstvennogo universiteta. Seriya A, gumanitarnye nauki, 1 , s. 18 23.

Borutskaya, S. B., Vasilyev, S. V., Yemialyanchyk, V. A. 2015. The Population of Polotsk in the $17-18^{\text {th }}$ Centuries According to Anthropological Data. International Journal of Anthropology, V, 30, 1, p. 27-42. 
Nathan, H., Haas, N. 1966. On the presence of cribra orbitalia in apes and monkeys. American Journal of Physical Anthropology, V, 24, p. 351-360.

Piontek, J. 1996. Biologia populacji pradziejowych. Zarys metodyczny. Poznań: UAM.

Ubelaker, D.H. 1989. Human skeletal remains. Excavation, analysis, interpretation. Washington: Taraxacum.

\section{A. Yemialyanchyk}

\section{MEDIEVAL POPULATION OF POLOTSK ACCORDING TO ANTHROPOLOGICAL DATA}

The aim of this study was to analyze human skeletal remains from $13^{\text {th }}-14^{\text {th }}$ centuries burials discovered on the territory of the Lower Castle in Polotsk, Belarus. The article deals with the morphological characteristics of medieval urban population and skeletal stress indicators such as mortality and cribra orbitalia.

According to most craniological characteristics, a series of male skulls from Polotsk of the $13^{\text {th }}-14^{\text {th }}$ centuries is similar to a sample of the medieval rural population of Polotsk land from burial mounds of the $11^{\text {th }}$ $13^{\text {th }}$ centuries. The differences relate to an increase in the cranial index in the later Polotsk series, which reflects the onset of epoch-making brachycephalization. In addition, Polotsk urban population differs from the rural population in a number of features characterizing the structural features of the facial skeleton (a higher face, a larger index of facial protrusion, a smaller protrusion of the nose). These differences can be genetically determined and indicate the participation of the alien component in the formation of Polotsk medieval population.

The body length of adult men from Polotsk varies within $162-175 \mathrm{~cm}$ and averages $169.5 \mathrm{~cm}$. The body length of adult women varies within $147-159 \mathrm{~cm}$ and averages $156 \mathrm{~cm}$. Compared to the later Polotsk population of $17^{\text {th }}-18^{\text {th }}$ centuries, the medieval urban population was taller $(2.5 \mathrm{~cm}$ in men and $2 \mathrm{~cm}$ in women).

The average age of adult death in the studied group was 35.1 years. The average age of death for Polotsk women was 3 years less than for men.

The group of Polotsk medieval population is characterized by relatively high frequencies of cribra orbitalia. Among adults, the indicator is present in $32.2 \%$ of cases, among children - in $55.5 \%$ of cases.

Compared with the rural population of the $11^{\text {th }}$ $13^{\text {th }}$ centuries urban population of Polotsk of the $13^{\text {th }}$ $14^{\text {th }}$ centuries had higher mortality rates and increased incidence of cribra orbitalia, which indicates deterioration in general health in Polotsk urban population. The most probable causes of this phenomenon were, on the one hand, negative factors of urbanization, and on the other hand, the cooling of the climate, which began in Europe in the $14^{\text {th }}$ century and led to deterioration in the living conditions of a significant part of the region's population.

Keywords: Polotsk, $13^{\text {th }}-14^{\text {th }}$ centuries, craniology, paleodemography, cribra orbitalia.

\section{B. А. Слельянчик}

\section{СЕРЕДНЬОВІЧНЕ НАСЕЛЕННЯ ПОЛОЦЬКА ЗА АНТРОПОЛОГІЧНИ- МИ ДАНИМИ}

Метою цього дослідження е аналіз людських скелетних решток поховань XIII-XIV ст., виявлених на території Нижнього замку в Полоцьку, Білорусь. У статті розглянуто морфологічні характеристики середньовічного міського населення і показники скелетного стресу, такі як смертність та cribra orbitalia.

За більшістю краніологічних характеристик серія чоловічих черепів з Полоцька XIII-XIV ст. схожа на зразок середньовічного сільського населення Полоцької землі з курганів XI-XIII ст. Відмінності стосуються збільшення черепного індексу в пізніших Полоцьких рядах, що відображае початок епохи брахіцефалізації. Крім того, міське населення Полоцька відрізняеться від сільського за низкою ознак, що характеризують особливості будови лицьового скелета (більш високе обличчя, більший показник випинання обличчя, менший виступ носа). Ці відмінності можуть бути генетично детермінованими та свідчити про участь чужорідного компоненту у формуванні полоцького середньовічного населення.

Довжина тіла дорослих чоловіків з Полоцька коливається в межах $162-175$ см, в середньому становить 169,5 см. Довжина тіла дорослих жінок коливається в межах 147-159 см, в середньому становить 156 см. Порівняно з пізнішим населенням Полоцька XVII-XVIII ст., середньовічне міське населення було вищим на 2,5 см у чоловіків і 2 см у жінок.

Середній вік смерті дорослих у досліджуваній групі становив 35,1 року. Середній вік смерті для полоцьких жінок був на 3 роки менший, ніж для чоловіків.

Група середньовічного населення Полоцька характеризуеться відносно високими частотами cribra orbitalia. Серед дорослих показник присутній у 32,2 \% випадків, серед дітей - у 55,5 \% випадків.

У порівнянні із сільським населенням XI-XIII ст. міське населення Полоцька XIII-XIV ст. мало вищі показники смертності та збільшення захворюваності на cribra orbitalia, що свідчить про погіршення загального стану здоров'я міського населення Полоцька. Найвірогіднішими причинами цього явища були, з одного боку, негативні фрактори урбанізації, а з іншого - охолодження клімату, що розпочалося в Свропі в XIV ст. і призвело до погіршення умов життя значної частини населення регіону.

Ключові слова: Полоцьк, XIII-XIV ст., краніологія, палеодемографія, cribra orbitalia.

Одержано 14.04.2020

ЄМЕЛЬЯНЧИК Вольга, кандидат біологічних наук, доцент, Полоцький державний університет, вул. Блохіна, 29, Новополоцьк, 211440, Беларусь.

YEMIALYANCHYK Volha, PhD in Biological Sciences, Associate Professor, Polotsk State University, Blokhin Str., 29, Novopolotsk, 211440, Belarus.

ORCID: 0000-0002-8813-4411, e-mail: o.emeljanchik@ psu.by. 